\title{
Influence of rainfall on the discharge, nutrient concentrations and loads of a stream of the "Pampa Ondulada" (Buenos Aires, Argentina)
}

\author{
S. Arreghini ${ }^{1,2}$, L. de Cabo ${ }^{2}$, R. Seoane ${ }^{3,4,5}$, N. Tomazin ${ }^{3}$, R. Serafíni ${ }^{2}$, and A. F. de Iorio ${ }^{1}$ \\ ${ }^{1}$ Cátedra de Química Analítica, Departamento de Recursos Naturales y Ambiente, Facultad de Agronomía, \\ Universidad de Buenos Aires, Av. San Martín 4453, 1417 Buenos Aires, Argentina. sarreghi@agro.uba.ar \\ 2 Museo Argentino de Ciencias Naturales "Bernardino Rivadavia”, Av. Angel Gallardo 470, \\ 1405 Buenos Aires, Argentina. 1decabo@macn.gov.ar. \\ ${ }^{3}$ Instituto Nacional del Agua \\ ${ }^{4}$ Departamento de Hidraúlica, Facultad de Ingeniería, Universidad de Buenos Aires, Av. Las Heras 2214 , \\ 1127 Buenos Aires, Argentina \\ 5 CONICET
}

\begin{abstract}
The basin area of the Durazno Stream covers approx. $360 \mathrm{~km}^{2}$ of a plain with a gentle slope, mainly devoted to cattle farming and agriculture. This study examines the variability of chemical composition of surface water of the stream in relation to stream discharge, estimated from a hydrological deterministic model from rainfall data. Fifteen samplings were carried out, four in high flow condition and the rest in baseline flow. In each sampling, the main physico-chemical variables were determined. Since discharge data from this stream were not available, it was estimated in situ through an instantaneous unitary hydrograph model. Both estimations of stream discharge were similar. The main forms of dissolved inorganic nitrogen were ammonium and nitrate. The four significant components of PCA that explained $84.4 \%$ of total variance were: mineral component, particulate matter content, ammonium and dissolved phosphorus levels, and nitrates' level. The decreased concentrations of major ions and conductivity during high flow condition suggest solutes' dilution by the massive inflow of water originated by rainfalls. The highest concentrations and loads of suspended solids (SS) (86 mg/1 and $22638 \mathrm{~kg} /$ day) and particulate organic carbon (POC) $(3.1 \mathrm{mg} / \mathrm{l}$ and $832 \mathrm{~kg} /$ day) were observed in the sample obtained during the rising limb of the hydrograph following a drought period, suggesting that basin erosive processes are more important during the first hours of the storm. Three of the samplings that were carried out in high flow conditions showed low mineral and nutrient content that revealed better water quality. In contrast, the sampling with the greatest total runoff $(14.1 \mathrm{~mm})$ showed high concentrations of ammonium $(1205 \mu \mathrm{g} / \mathrm{l})$ and dissolved phosphorus $(561 \mu \mathrm{g} / \mathrm{l})$, suggesting that a long stagnant period on soils with low permeability, could favor reduction processes of nitrate to ammonium and mobilization of dissolved phosphorus to overlying water. The nutrients' loads increased in high flow conditions most likely due to runoff from the riverbank soils. The rise of nutrients, SS, POC and total organic carbon (TOC), loads in the same or in higher proportion than the stream discharge, alerts on the risk of contamination of surface water in an agricultural basin.
\end{abstract}

Keywords: runoff, hydrological models, nutrients, stream discharge, lowland river

\section{RESUMEN}

La cuenca del Arroyo Durazno abarca aproximadamente $360 \mathrm{~km}^{2}$ de una llanura con suave pendiente, dedicada principalmente a ganadería y agricultura. Este estudio examina la variabilidad en la composición química del agua superficial del arroyo en relación con el caudal estimado a través de un modelo hidrológico determinístico a partir de los datos de lluvia. Se realizaron quince muestreos: cuatro en condiciones de alto caudal, los restantes en caudal base. En cada muestreo se determinaron las principales variables fisico-químicas. Dado que no existen datos publicados de caudal de este arroyo, se lo estimó in situ, y a partir del modelo de hidrograma unitario. Ambas estimaciones resultaron similares. Las principales formas de nitrógeno inorgánico disuelto fueron amonio y nitrato. Los primeros 4 factores extraídos del PCA que explicaron $84.4 \%$ de la varianza total fueron: componente mineral, contenido de material particulado, niveles de amonio y fósforo disuelto y nivel de nitratos. El decrecimiento de iones mayoritarios y conductividad durante las condiciones de alto caudal sugiere su dilución por la entrada masiva de agua por lluvias. Las mayores concentraciones y cargas de sólidos suspendidos (SS) (86 mg/l y $22638 \mathrm{~kg} /$ día) y carbono orgánico particulado (COP) $(3.1 \mathrm{mg} / \mathrm{l}$ y $832 \mathrm{~kg} /$ dia) se hallaron en el muestreo realizado durante la 
rama ascendente del hidrograma posterior a un periodo de sequía, sugiriendo que los procesos erosivos de la cuenca son más importantes en las primeras horas de la tormenta. Tres de los muestreos realizados en condiciones de alto caudal presentaron bajo contenido mineral y de nutrientes, indicando mejor calidad de agua. En cambio en el muestreo de mayor lámina de escorrentía acumulada $(14.1 \mathrm{~mm})$ las concentraciones de amonio $(1205 \mu \mathrm{g} / \mathrm{l})$ y fósforo disuelto (561 $\mu \mathrm{g} / \mathrm{l})$ fueron elevadas, sugiriendo que un prolongado periodo de estancamiento en un suelo de baja permeabilidad favorecería los procesos de reducción de nitratos a amonio y la movilización de fósforo disuelto al agua de inundación. Las cargas de nutrientes aumentaron en condiciones de alto caudal probablemente debido al aporte por escorrentía de suelos ribereños. El ascenso en las cargas de nutrientes, SS, COP y carbono orgánico total en igual o mayor magnitud que el caudal alerta sobre el riesgo de contaminación de las aguas superficiales en una cuenca agrícola.

Palabras clave: escorrentía, modelos hidrológicos, nutrientes, caudal, río de llanura

\section{INTRODUCTION}

Stream water composition is influenced by the stream discharge, runoff, land use, edaphology, geomorphology, topography, and the activity of the organisms of its' drainage basin. The river corridors in the alluvial plains have been dramatically transformed by man over the centuries, especially in temperate countries (Prat \& Ward, 1994). First, the riparian vegetation and natural aquatic communities on the alluvial plain were converted into agricultural systems by deforestation and refilling of lowlands. Thereafter, under the pressure of increasing population densities, they were converted into industrial and residential areas. The main contamination pathway into surface waters is through soil-associated contaminants following erosion, but also, subsurface direct flow during storms, contributes to lateral input into small streams (Honisch, et al., 2002).

Because of the advance of agricultural and urban boundaries, the natural ecosystem of the prairie in the Argentine Pampas has disappeared (Solbrig, 1999a), with the consequent loss of at least three types of native woods (Morello \& Mateucci, 1999a). The riparian zones of several streams in the Buenos Aires province have been completely modified (Faggi et al., 1999). Although the Pampean region presents edaphic characteristics that allow for its' dry farming (Solbrig, 1999b), important technological changes incorporated during the last three decades have accelerated the increase in agricultural productivity, mainly in the "Pampa Ondulada"
(Viglizzo et al., 2002). Nevertheless, both present and future achievements in production volumes have still unknown ecological costs. Surface and groundwater contamination is undoubtedly one of the critical matters for rural sustainability of this region (Morello \& Matteucci, 1999b). Unfortunately, the limnology of streams in this area has been scarcely studied; for example, there is no published information on the Durazno Stream.

To describe the water quality dynamics we propose a methodology based in discharge estimation by an instantaneous unit hydrograph model (IUH) together with chemical and physical measurements in stream water under different hydrological conditions. Principal component analysis (PCA) has been widely used, as they are unbiased methods that can indicate associations between samples and/or variables (Vega et al., 1998). Using this methodology, in this study we aim at examining the temporal changes of water composition of the Durazno stream focusing on the levels of organic carbon, nitrate, ammonium, and phosphate in an agricultural basin in relation to stream discharge estimated through a hydrological deterministic model from rainfall data.

\section{MATERIALS AND METHODS}

\section{Study area}

The Durazno Stream is one of the main tributaries of The Reconquista River (Fig. 1). The basin 


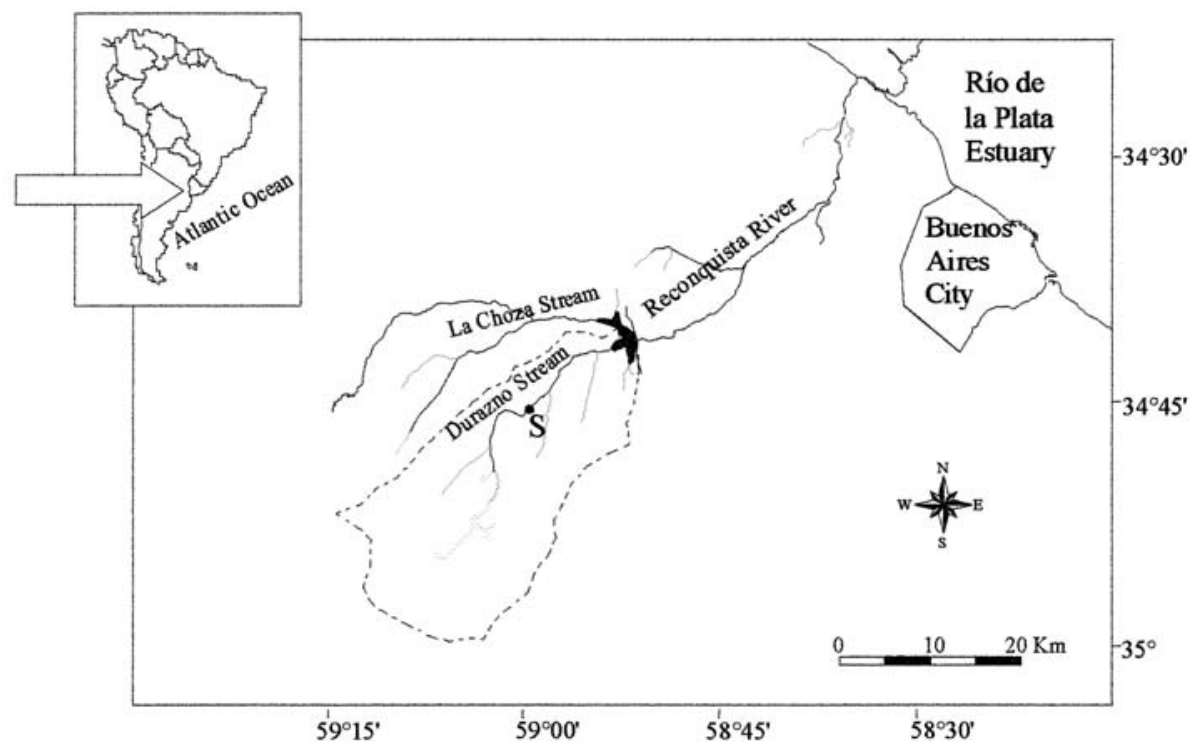

Figure 1. Durazno Stream Basin. S: sampling site. Cuenca del Arroyo Durazno. S: Sitio de muestreo.

area is $360 \mathrm{~km}^{2}$ and the stream length is $32 \mathrm{~km}$. The main topographic and geomorphologic characteristics of its basin are area ratio: 3.4 , bifurcation ratio: 3.2 , and length ratio: 1.7 , which quantitatively agree with the Horton's laws of basin drainage. These parameters were estimated for the basin using Strahler`s ordering procedure (Bras, 1990). The relief includes very flat plains and extended hillocks (approximately $20 \mathrm{~m}$ a.s.l.). The basin slope is $0.05 \%$. The soils of the basin are poorly drained, with low permeability, the prevailing types being: Argialbolls $(37 \%)$, Natraqualfs $(34 \%)$, Natraquolls (12\%), and Hapludolls (11 \%). They present a C:N ratio of 8$10.9 ; \mathrm{pH}$ varies from strongly acidic to slightly alkaline, and the concentration of exchangeable cations (mainly sodium and potassium) is high (INTA, 1997). Sixty percent of the land is devoted to cattle farming in natural pastures, and $20 \%$ to agriculture (http://www.indec.mecon.ar).

According to Köppen's classification, the region is characterized by temperate humid climate with annual mean rainfalls of $1055 \mathrm{~mm}$ for the period 1961-1990. Maximum and minimum rainfalls occur in March $(125 \mathrm{~mm} / \mathrm{month})$ and in June $(56 \mathrm{~mm} / \mathrm{month})$ respectively. Maximum temperatures occur in January $\left(24.3^{\circ} \mathrm{C}\right)$ and minimum in July $\left(11.1^{\circ} \mathrm{C}\right)$ (Secretariat of the World Meteorological Organization, 1996). The excess moisture period is from March to November (INTA, 1997). The sampling site was located in the Durazno Stream, $27 \mathrm{~km}$ downstream from its source (Fig. 1). The studied drainage area comprises $257 \mathrm{~km}^{2}$. According to Strahler's classification (Gordon et al., 1994), the study site is in a second-order stream.

\section{Hydrological estimations}

Because discharge data from the Durazno basin were not available, the stream discharge corresponding to each rainfall event was estimated from the instantaneous unitary hydrograph (IUH) model (Clark, 1945). Stream discharge is composed of direct runoff and baseline flow. Direct runoff is defined as the portion of the hydrograph that responds relatively quickly and is clearly related to a given storm event (Bras 1990). Baseline flow is the volume of water representing the groundwater contribution (Gordon et al., 1994). The applied method consists of the following steps: 1) the 
estimation of the effective rainfall for each rain event by means of an infiltration method (Soil Conservation Service, 1972); and 2) the transformation of effective rainfall in a stream discharge by the IUH model (Clark, 1945). The use of this last model shows uncertainty on factors such as the estimation of intrinsic parameters of the model, the uneven distribution of rainfall, and the lack of flow measurements for its calibration. However, when only scarce data are available, the IUH model is the one used most often for the estimation of direct runoff in small basins. The software used was the HECMHS 2.0 (Hoggan, 1989).

The maximum soil storage capacity $S[\mathrm{~mm}]$ is:

$$
S=\frac{25400}{C N}-254
$$

where $\mathrm{CN}$ is the curve number tabulated as a function of soil type and vegetation cover. For the studied basin, a $\mathrm{CN}=70$ was adopted. This value falls within the confidence intervals suggested by McCuen (2002) for basins with similar characteristics.

The direct runoff, or effective precipitation $P e[\mathrm{~mm}]$, was calculated as:

$$
P e=\frac{(P-0.2 S)}{P+0.8 S}
$$

where $P[\mathrm{~mm}]$ is total rainfall. Rainfall records correspond to the nearest pluviometer $(15 \mathrm{~km}$ away from the study site).

The parameters required by the IUH model used to model rainfall-runoff transformations are the concentration time of the basin $\left(t_{c}\right)$ and the basin storage constant $(K)$, which can be estimated from the topographic characteristics of the basin. Time of concentration is the time after commencement of the rainfall excess when all portions of the drainage basin are contributing simultaneously to the flow at the outlet (Maidment, 1992). The basin storage coefficient is an index of the temporary storage of excess precipitation in the watershed as it drains to the outlet point. The equations provided by Kirpich (1940) and Wilson \& Brown (1992) were used to estimate $t_{c}$ and $K$ respectively.
On each sampling date the stream discharge (Q) was estimated in situ from the section of the streambed, considering depth profile and water velocity, by measuring the time taken by a floating object to cover a known distance downstream (Gordon et al., 1994). These results were compared with the discharge values estimated from the IUH model. The hydrographs were done with the mean baseline flow $\left(0.06 \mathrm{~m}^{3} / \mathrm{s}\right)$ obtained from non-rainfall events discharge values.

\section{Sampling design}

Stream samplings were carried out on 15 dates from 1996 to 2000 considering different values of stream discharge. For the aim of this study, the selection of the Durazno Stream Basin was based on the following characteristics: the absence of major anthropic impacts such as dams and storage reservoirs, and for limited land use change during the period recorded. Four rainfall-stream discharge events (high flow conditions) were sampled, two in summer (March 1998 and March 1999) and two in winter (August 1996 and July 1999). The remaining samplings were carried out in baseline flow conditions.

\section{Analytical procedures}

Sample containers were $500 \mathrm{ml}$ polyethylene bottles provided with hermetic-locking caps. Bottles and caps were cleaned by soaking them into $30 \% \mathrm{HCl}$ for three days, rinsed with deionized water, drained, and stored until required. Samples were collected by means of a pump from the middle of the stream. Prior to sample collection, the sampling device and the containers were rinsed twice with the water to be sampled. Dissolved oxygen (DO) (YSI 51B oxymeter), pH (ORION pHmeter 250A), electrical conductivity (EC) (LUFTMAN conductimeter), temperature, and water depth measurements were performed in situ. Triplicate samples were taken out and immediately filtered through Whatman GF/C filters into acidwashed polyethylene bottles. Samples were 
immediately placed at $4^{\circ} \mathrm{C}$ and transported to the laboratory where analyses were accomplished within three days. Concentrations of different solutes were determined using the following analytical methods: soluble reactive phosphorus (SRP) with ascorbic molibdate, nitrates $\left(\mathrm{N}^{-\mathrm{NO}_{3}}{ }^{-}\right)$by reduction with hydrazine sulfate, nitrites $\left({\left.\mathrm{N}-\mathrm{NO}_{2}-\right)}^{-}\right)$by diazotation according to Strickland and Parsons (1968), ammonium $\left(\mathrm{N}^{-\mathrm{NH}_{4}}{ }^{+}\right)$by the indophenol blue method, bicarbonates $\left(\mathrm{HCO}_{3}^{-}\right)$by volumetry according to Mackereth et al. (1989), calcium $\left(\mathrm{Ca}^{2+}\right)$ and magnesium $\left(\mathrm{Mg}^{2+}\right)$ by titration with EDTA, sodium $\left(\mathrm{Na}^{+}\right)$and potassium $\left(\mathrm{K}^{+}\right)$by flame photometry, sulfates $\left(\mathrm{SO}_{4}{ }^{2-}\right)$ by turbidimetry, and chlorides $\left(\mathrm{Cl}^{-}\right)$by titration with silver nitrate (APHA, 1992). The quantity of suspended solids (SS) was determined by gravimetry, whereas the digestion of these same solids with sulphochromic solution was used to determine particulate organic carbon (POC) (Golterman et al., 1978). Total organic carbon (TOC) was determined on unfiltered water by digestion with sulphochromic solution (Golterman et al., 1978). Dissolved organic carbon (DOC) was estimated through the difference between TOC and POC. The loads of the major ions, nutrients and suspended solids were estimated by multiplying the stream dis- charge estimated from IUH model by their concentration for each sampling date. Under baseline flow conditions, the loads were estimated using the mean baseline flow measured.

\section{Statistical analyses}

Pearson correlation analysis was used to examine relationships between measured variables $(p<0.05)$. Exploratory data analysis was performed by linear display methods (principal component analysis) on experimental data normalized to zero mean and unit variance. The Kaiser criterion was used to identify the number of principal components to be retained in order to encompass the underlying data structure (Pla, 1986). This criterion retains only factors with eigenvalues greater than 1 . The statistical analyses were performed with GenStat 7.1 (2003).

\section{RESULTS}

\section{Hydrological analysis}

For the four rainfall-stream discharge events sampled, stream discharge values estimated from the IUH model were close to those estimated in situ (Table 1). The figures 2.a. and 2.d. show

Table 1. Stream discharge estimation according to Gordon et al. (1994), daily rainfall, effective rainfall estimated according to Soil Conservation Service (1972), and stream discharge of Durazno estimated according to the IUH hydrograph model and total runoff for high flow condition. Caudal del arroyo Durazno estimado según Gordon et al. (1994), precipitación diaria, precipitación efectiva estimada de acuerdo a Soil Conservation Service (1972) y caudal del Arroyo Durazno estimado según el modelo del HUI y lámina de escorrentía, para condiciones de alto caudal.

\begin{tabular}{cccccc}
\hline $\begin{array}{c}\text { Sampling dates } \\
\text { on high flow } \\
\text { condition }\end{array}$ & $\begin{array}{c}\text { Stream discharge } \\
\text { according to } \\
\text { Gordon } \text { et } \text { al. } \\
(\mathbf{1 9 9 4 )}\end{array}$ & $\begin{array}{c}\text { Daily } \\
\text { rainfall }\end{array}$ & $\begin{array}{c}\text { Effective } \\
\text { rainfall }\end{array}$ & $\begin{array}{c}\text { Stream discharge } \\
\text { according } \\
\text { to IUH model }\end{array}$ & Total runoff \\
& $\mathbf{( \mathbf { m } ^ { 3 } / \mathbf { s } )}$ & $\mathbf{( m m )}$ & $\mathbf{( m m )}$ & $\mathbf{( \mathbf { m } ^ { 3 } \mathbf { s } )}$ & $\mathbf{( m m )}$ \\
\hline Aug-96 & 2.67 & 46 & 4.4 & 3.06 & 0.2 \\
Mar-98 & 3.82 & 75 & 9.1 & 3.70 & 14.1 \\
Mar-99 & 3.59 & 55 & 7.8 & 4.50 & 2.7 \\
Jul-99 & 5.34 & 59 & 9.5 & 4.76 & 8.9 \\
\hline
\end{tabular}



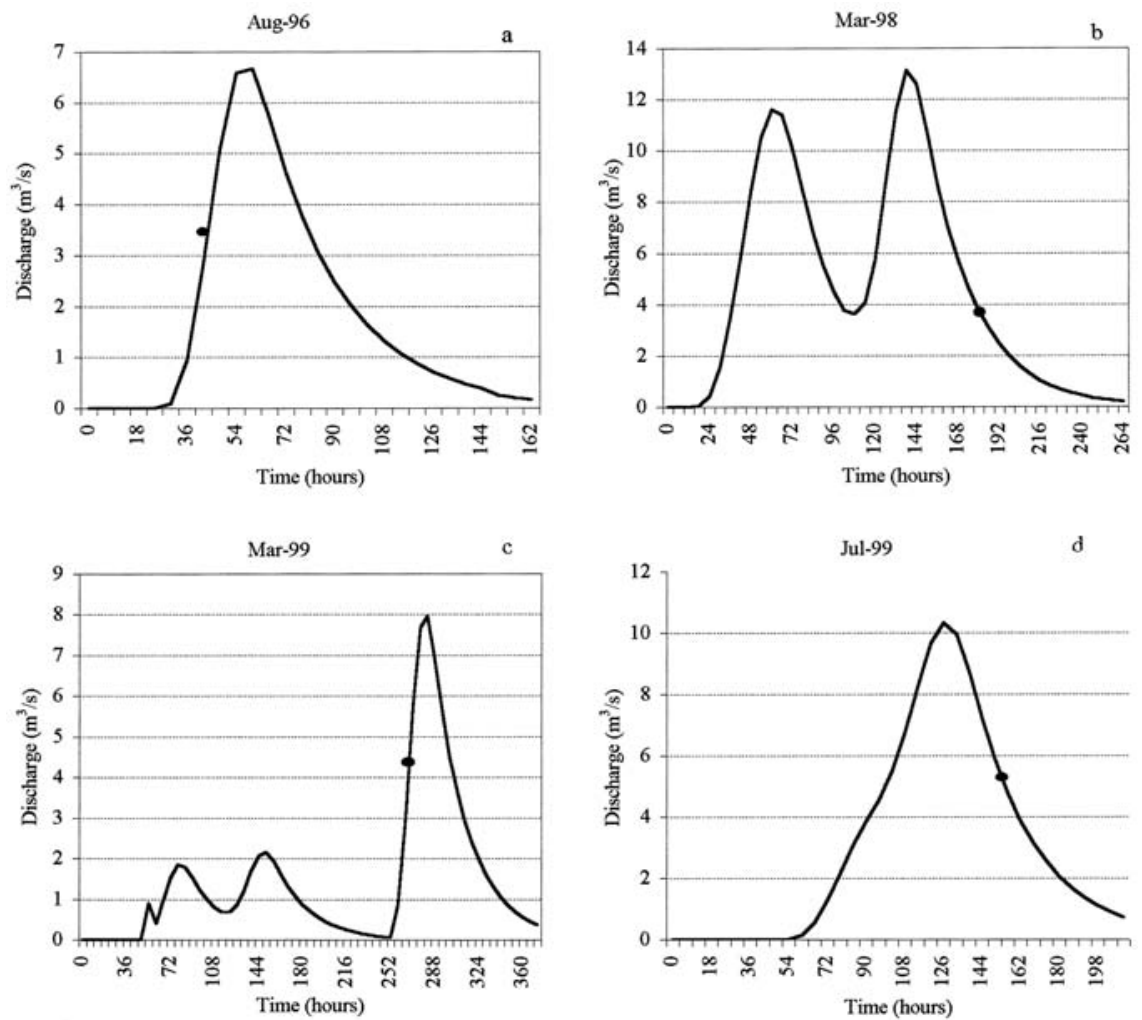

Figure 2. Hydrographs of stream discharge corresponding to high flow conditions. - Sampling date. Hidrogramas de caudal para condiciones de alto caudal. $\cdot$ Fecha de muestreo.

simple hydrographs that indicate the behaviour of the river basin during the occurrence of the rainfall events of a single pulse. The figures 2.b. and 2.c. represent the characteristic type of hydrographs for a storm composed of more than one pulse. This second kind of hydrographs observed with an antecedent moisture condition of the soil is different from the ones produced by only one pulse of rainfall. The former can present a greater peak in the hydrograph owing to the other rainfall pulses. The samples from August 1996 and March 1999 were taken in the rising limb of the hydrograph while the ones of March 1998 and July 1999 in the recession limb.

\section{Dynamics of the physico-chemical variables of the stream water}

Mean DO of surface stream water was 7.0 \pm 2.1 $\mathrm{mg} / \mathrm{l}$ (Table 2). Dissolved oxygen did not show significant correlations with temperature or nutrient concentrations (Table 3 ).

On average, EC was $1508 \pm 817 \mu \mathrm{S} / \mathrm{cm}$. Bicarbonates and sodium were the dominant major ions: $10 \mathrm{meq} / 1$ and $7.6 \mathrm{meq} / 1$ respectively. The $\mathrm{pH}$ values were slightly basic (around 8). The correlations between EC and the concentrations of the major ions with the stream discharge were inverse and significant (Table 3).

The main forms of dissolved inorganic nitrogen were ammonium and nitrates, whereas nitrites exceeded $10 \%$ only on three occasions. In three of the samplings under high flow conditions (August 1996, March 1999, and July 1999) nitrate concentrations were higher than ammonium concentrations whereas the opposite relationship was observed in March of 1998. This last case exhibited the highest total runoff (Table 1). A great variation in nitrate and ammonium concentrations was found under baseline 
Table 2. Physical and chemical variables of the Durazno Stream. Variables fisicas y químicas del Arroyo Durazno.

\begin{tabular}{|c|c|c|c|c|c|c|c|c|c|c|c|c|c|c|c|c|c|}
\hline & Apr-96 & Jun-96 & Aug-96 & Oct-96 & Dec-96 & Feb-97 & May-97 & Aug-97 & Dec-97 & Mar-98 & Dec-98 & Mar-99 & Jun-99 & Jul-9 & 9 Dec-00 & Mean & $\pm \mathrm{SD}$ \\
\hline DO (mg/l) & 5.4 & 12.5 & 7.2 & 4.8 & 7.0 & 8.1 & 10.1 & 6.0 & 4.8 & 6.8 & 6.6 & 7.0 & 4.5 & 6.0 & 8.4 & 7.0 & \pm 2.1 \\
\hline Temperature $\left({ }^{\circ} \mathrm{C}\right)$ & 20.0 & 6.0 & 8.5 & 18.0 & 22.5 & 16.5 & 9.5 & 15.0 & 24.1 & 19.0 & 20.0 & 22.8 & 13.1 & 7.4 & 21.0 & 16.2 & \pm 6.0 \\
\hline $\mathrm{EC}(\mu \mathrm{S} / \mathrm{cm})$ & 1827 & 2357 & 352 & 1000 & 2170 & 2227 & 2600 & 1530 & 1955 & 355 & 1902 & 229 & 1930 & 410 & 1770 & \# & \pm 817 \\
\hline $\mathrm{SS}(\mathrm{mg} / \mathrm{l})$ & 36 & 57 & 86 & 111 & 8 & 27 & 22 & 24 & 50 & 30 & 13 & 30 & 12 & 31 & 6 & 36 & \pm 29 \\
\hline $\mathrm{pH}$ & 8.3 & 8.4 & 8.1 & 8.0 & 8.3 & 7.8 & 8.0 & 8.0 & 7.6 & 7.4 & 8.4 & 7.9 & 8.1 & 8.2 & 8.1 & 8.0 & \pm 0.3 \\
\hline $\mathrm{N}-\mathrm{NH}_{4}{ }^{+}(\mu \mathrm{g} / \mathrm{l})$ & 483 & 43 & 198 & 155 & 92 & 450 & 440 & 367 & 1219 & 1205 & 700 & 42 & 174 & 20 & 72 & 377 & \pm 393 \\
\hline $\mathrm{N}^{-\mathrm{NO}_{3}^{-}}{ }^{-}(\mu \mathrm{g} / \mathrm{l})$ & 117 & 701 & 361 & 217 & 853 & 169 & 370 & 1038 & 205 & 402 & 134 & 137 & 35 & 132 & 205 & 338 & \pm 297 \\
\hline $\mathrm{N}^{-\mathrm{NO}_{2}}{ }_{2}^{-}(\mu \mathrm{g} / \mathrm{l})$ & 46 & 65 & 57 & 108 & 77 & 50 & 74 & 55 & 87 & 108 & 32 & 30 & 11 & 27 & 23 & 57 & \pm 30 \\
\hline $\operatorname{SRP}(\mu \mathrm{g} / \mathrm{l})$ & 67 & 183 & 305 & 684 & 73 & 292 & 558 & 428 & 625 & 561 & 143 & 159 & 70 & 290 & 83 & 301 & \pm 218 \\
\hline POC (mg/l) & 2.0 & 2.7 & 3.1 & 2.5 & 0.5 & 1.5 & 0.4 & 1.1 & 0.7 & 0.8 & 1.3 & 0.9 & 0.6 & 1.8 & 0.1 & 1.3 & \pm 0.9 \\
\hline $\mathrm{TOC}(\mathrm{mg} / \mathrm{l})$ & 10.4 & 21.6 & 51.8 & 24.7 & 3.8 & 8.9 & 19.5 & 29.4 & 37.9 & 35.3 & 9.4 & 20.2 & 12.4 & 6.9 & 5.3 & 19.8 & \pm 14 \\
\hline $\mathrm{DOC}(\mathrm{mg} / \mathrm{l})$ & 8.3 & 18.9 & 48.6 & 22.2 & 3.3 & 7.3 & 19.1 & 28.3 & 37.2 & 34.4 & 8.1 & 19.3 & 11.8 & 5.1 & 5.2 & 18.5 & \pm 14 \\
\hline $\mathrm{Ca}^{+2}(\mathrm{mg} / \mathrm{l})$ & 36 & 45 & 9 & 35 & 36 & 40 & 42 & 37 & 33 & 9 & 19 & 3 & 33 & 6 & 39 & 28 & \pm 15 \\
\hline $\mathrm{Mg}^{+2}(\mathrm{mg} / \mathrm{l})$ & 28 & 33 & 6 & 23 & 31 & 26 & 31 & 21 & 22 & 4 & 29 & 5 & 18 & 2 & 24 & 20 & \pm 11 \\
\hline $\mathrm{Na}^{+}(\mathrm{mg} / \mathrm{l})$ & 420 & 349 & 73 & 198 & 279 & 259 & 234 & 236 & 247 & 68 & 476 & 22 & 285 & 51 & 260 & 230 & \pm 133 \\
\hline $\mathrm{K}^{+}(\mathrm{mg} / \mathrm{l})$ & 19 & 17 & 10 & 14 & 18 & 14 & 13 & 14 & 18 & 9 & 17 & 9 & 12 & 12 & 14 & 14 & \pm 3 \\
\hline $\mathrm{HCO}_{3}^{-}(\mathrm{mg} / \mathrm{l})$ & 604 & 729 & 179 & 479 & 601 & 533 & 500 & 451 & 484 & 177 & 745 & 118 & 546 & 172 & 665 & 465 & \pm 209 \\
\hline $\mathrm{SO}_{4}^{2-}(\mathrm{mg} / \mathrm{l})$ & 108 & 52 & 32 & 102 & 46 & 74 & 82 & 120 & 80 & 19 & 155 & 15 & 83 & 18 & 183 & 78 & \pm 50 \\
\hline $\mathrm{Cl}^{-}(\mathrm{mg} / \mathrm{l})$ & 226 & 250 & 26 & 169 & 234 & 234 & 237 & 170 & 199 & 32 & 317 & 12 & 135 & 24 & 193 & 164 & \pm 97 \\
\hline Hardness $\left(\mathrm{mg} \mathrm{CaCO}_{3} / \mathrm{l}\right)$ & l) 207 & 252 & 48 & 181 & 219 & 207 & 233 & 181 & 174 & 42 & 169 & 28 & 159 & 26 & 200 & 155 & \pm 78 \\
\hline
\end{tabular}

flow conditions. On average, the SRP concentration was $301 \pm 218 \mu \mathrm{g} / \mathrm{l}$. Only a small fraction of the organic matter was in the particulate form, on average POC represented $9 \%$ of TOC.

Four principal components (PC) of the Principal Component Analysis were retained, which have eigenvalues greater than unity and explained $84,4 \%$ of the total variance. For the purpose of interpretation, "high" loading was defined as greater than 0.7 . Loadings of the four retained PCs are presented in Table 4. PC1 explains $43.1 \%$ of the total variance and is highly participated by stream discharge. EC, sodium, bicarbonate, chloride, and hardness

Table 3. Correlation matrix of the physico-chemical variables and the stream discharge (Q) used for Principal Components Analysis. Matriz de correlación de las variables fisico-químicas y el caudal $(Q)$ utilizados para el Análisis de Componentes Principales.

\begin{tabular}{|c|c|c|c|c|c|c|c|c|c|c|c|c|c|c|}
\hline & DO & TEMP & EC & SS & $\mathrm{N}-\mathrm{NH}_{4}{ }^{+}$ & $\mathrm{N}-\mathrm{NO}_{3}^{-}$ & SRP & POC & DOC & $\mathrm{Na}^{+}$ & $\mathrm{HCO}_{3}^{-}$ & $\mathrm{Cl}^{-}$ & Q & Hardness \\
\hline DO & 1.000 & & & & & & & & & & & & & \\
\hline TEMP & -0.443 & 1.000 & & & & & & & & & & & & \\
\hline $\mathrm{EC}$ & 0.393 & -0.011 & 1.000 & & & & & & & & & & & \\
\hline SS & -0.089 & -0.249 & -0.356 & 1.000 & & & & & & & & & & \\
\hline $\mathrm{N}-\mathrm{NH}_{4}{ }^{+}$ & -0.243 & 0.383 & 0.038 & -0.053 & 1.000 & & & & & & & & & \\
\hline $\mathrm{N}-\mathrm{NO}_{3}^{-}$ & 0.305 & -0.115 & 0.220 & -0.054 & -0.090 & 1.000 & & & & & & & & \\
\hline SRP & -0.211 & 0.006 & -0.145 & 0.553 & 0.555 & 0.028 & 1.000 & & & & & & & \\
\hline POC & 0.153 & -0.566 & -0.326 & 0.800 & -0.258 & 0.044 & 0.149 & 1.000 & & & & & & \\
\hline DOC & -0.128 & -0.098 & -0.397 & 0.588 & 0.447 & 0.152 & 0.582 & 0.385 & 1.000 & & & & & \\
\hline $\mathrm{Na}^{+}$ & 0.208 & 0.097 & 0.822 & -0.278 & 0.084 & 0.135 & -0.271 & -0.146 & -0.398 & 1.000 & & & & \\
\hline $\mathrm{HCO}_{3}^{-}$ & 0.311 & 0.092 & 0.868 & -0.251 & -0.055 & 0.169 & -0.287 & -0.177 & -0.471 & 0.955 & 1.000 & & & \\
\hline $\mathrm{Cl}^{-}$ & 0.316 & 0.138 & 0.899 & -0.233 & 0.098 & 0.205 & -0.101 & -0.190 & -0.408 & 0.936 & 0.937 & 1.000 & & \\
\hline Q & -0.151 & -0.202 & -0.850 & 0.073 & -0.037 & -0.247 & 0.021 & 0.197 & 0.176 & -0.820 & -0.866 & -0.867 & 1.000 & \\
\hline Hardness & 0.398 & 0.020 & 0.936 & -0.141 & -0.067 & 0.342 & -0.043 & -0.188 & -0.342 & 0.803 & 0.899 & 0.906 & -0.924 & 1.000 \\
\hline
\end{tabular}


Table 4. Eigenvalues, variance explained, and contribution of the variables to the four significant principal components of the PCA for 15 Durazno water samples. (Q: stream discharge). Autovalores, varianza explicada y contribución de las variables a los cuatro componentes significativos del Análisis de Componentes Principales realizado con las 15 muestras del agua del Arroyo Durazno. (Q: caudal).

\begin{tabular}{|c|c|c|c|c|}
\hline Variable & PC1 & PC2 & PC3 & PC4 \\
\hline DO & -0.59 & -0.377 & 0.478 & -0.422 \\
\hline TEMP & -0.125 & 0.581 & -0.572 & 0.093 \\
\hline $\mathrm{EC}$ & -0.944 & -0.098 & -0.059 & -0.077 \\
\hline SS & 0.410 & -0.770 & -0.168 & 0.379 \\
\hline $\mathrm{N}-\mathrm{NH}_{4}{ }^{+}$ & 0.045 & 0.071 & -0.850 & -0.195 \\
\hline $\mathrm{N}-\mathrm{NO}_{3}^{-}$ & -0.246 & -0.345 & 0.055 & -0.711 \\
\hline SRP & 0.296 & -0.443 & -0.700 & -0.083 \\
\hline $\mathrm{POC}$ & 0.339 & -0.782 & 0.266 & 0.317 \\
\hline DOC & 0.523 & -0.515 & -0.481 & -0.220 \\
\hline $\mathrm{Na}^{+}$ & -0.916 & -0.076 & -0.087 & 0.193 \\
\hline Hardness & -0.932 & -0.266 & -0.076 & -0.029 \\
\hline $\mathrm{HCO}_{3}^{-}$ & -0.961 & -0.099 & -0.003 & 0.171 \\
\hline $\mathrm{Cl}^{-}$ & -0.950 & -0.141 & -0.152 & 0.090 \\
\hline Q & 0.874 & 0.218 & 0.270 & -0.117 \\
\hline Eigenvalue & 6.039 & 2.433 & 2.215 & 1.125 \\
\hline$\%$ Variance explained & 43.1 & 17.4 & 15.8 & 8.0 \\
\hline$\%$ Cum. Variance & 43.1 & 60.5 & 76.3 & 84.4 \\
\hline
\end{tabular}

were positively correlated (Table 3 ) and have a high negative participation in PC1. PC2 explains $17.4 \%$ of the variance and includes suspended solids and POC (high negative loading), which were correlated (Table 3). PC3 explains $15.8 \%$ of the total variance and is highly negative contributed by ammonium and SRP. Finally, PC4 explains $8.0 \%$ of the total variability of the original data and is highly negative contributed by nitrates.

Figure 3.a. shows a plot of sample scores on the bi-dimensional plane defined by PC1 (mineral contents) and PC2 (particulate matter contents). High positive scores on factors 1 or 2 indicate low mineral contents and high stream discharge (PC1) or low suspended solids and POC contents (PC2). Figure 3.b. displays a plot of sample scores on the bi-dimensional plane defined by PC1 and PC3 (nutrient input). High positive scores on factors 1 or 3 indicate low mineral contents and high stream discharge (PC1) or low nutrient contents (PC3), thus indi-
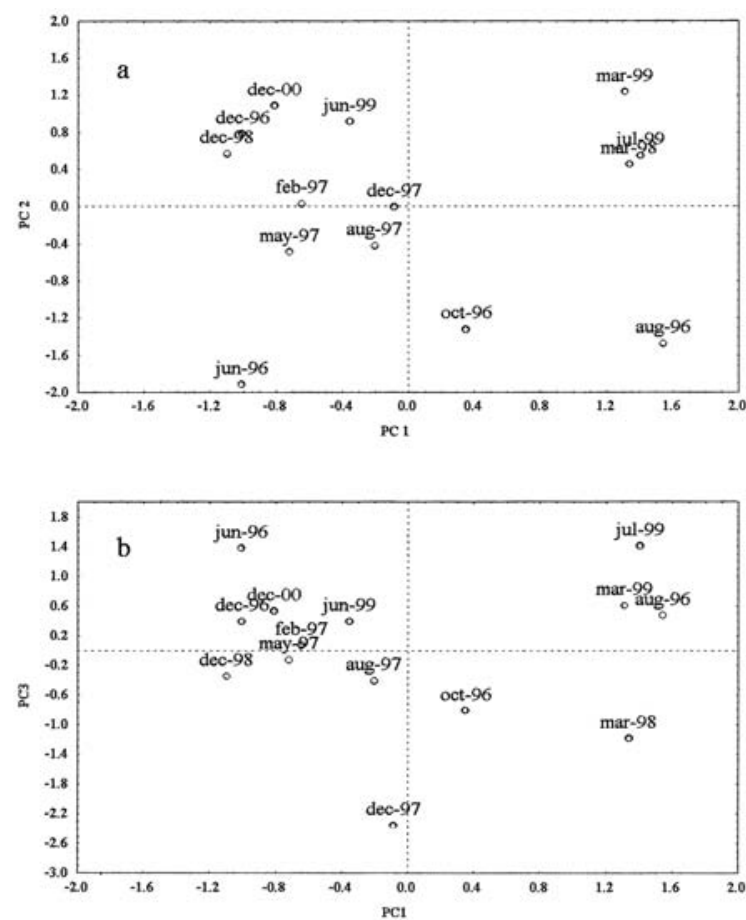

Figure 3. Location of the sampling dates in the plane determined by: (a) PC1 and PC2 and (b) PC1 and PC3 of Principal Components Analysis. Ubicación de las fechas de muestreos en el plano determinado por: (a) los componentes 1 y 2 y (b) componentes 1 y 3 del Análisis de Componentes Principales.

cating good water quality (July 1999, March 1999, and August 1996). The sampling of August 1996 was done under high flow conditions but showed higher concentrations of SS and POC. The sampling of March 1998 was done also under high flow conditions (projected onto positive PC1) but ammonium and SRP levels were higher (projected onto negative PC3).

The means of loads of all of the variables estimated under high flow conditions were higher than those estimated under baseline flow conditions (Table 5). The increase in the loads of SS, POC, and TOC were higher than corresponding increases in the stream discharge values. However, the increase of the load of the major ions was lower than that of the stream discharge, and the increase in loads of ammonium, nitrates, and SRP were similar to those of stream discharge. The sampling on March 1998 showed the highest loads of ammonium, nitrates, and SRP. 


\section{DISCUSSION}

Dissolved oxygen was never below $4 \mathrm{mg} / \mathrm{l}$, which is the lowest limit accepted for the protection of aquatic life (USEPA, 1986). The nutrient concentrations in the Durazno Stream are highly variable. Since the sampling site is far from urbanized areas, the presence of high nitrogen levels in surface water could have originated from the runoff of cattle-raising land and surrounding agricultural fields (Jarvie et al., 1998). The dominant major ions in the Durazno Stream are sodium and bicarbonates, as already reported for other streams of the "Pampa Ondulada" (Mercado, 1999; Modenutti, 1987; López et al., 1998). The soils in the basin area are predominantly natric, showing an increase in the proportion of clays in deeper horizons. The effect of sodium on the dispersion of clay and on the formation of a B-horizon of illuvial clay has long been recognized (USDA, 1999). Due to this effect, a weaker infiltration and a stronger runoff of these ions are to be expected on these soils, in spite of low regional slope.

Factors involved in the hydrochemistry variability of the Durazno Stream are: mineral component, particulate matter content, and nutrient level. The mineral component of the stream water is strongly influenced by the stream discharge. The decreased concentrations of the major ions and the EC during high flow condition suggest that concentrations of solutes had been diluted by the massive inflow of water originated from rainfalls. In the hydrograph, the representation of samplings obtained under high flow conditions showed distinct positions, however, these samples exhibited a similar behavior on mineral components. The second factor composition can be explained taking into account that some of the suspended solids belong to the organic matter component. The sampling of August 1996 was done during a rising limb of the hydrograph following drought. It showed higher concentrations and higher loads of SS, DOC, and POC, suggesting that erosive processes that take place in the basin during the first storm hours. Bernal et al. (2002) found similar behavior for DOC concentration. During storm events, DOC increases rapidly due to sediment remobilization processes and carrier transport with soil particles (Honisch et al., 2002). The third factor is likely related to decomposition processes of organic matter leading to the release of ammonium and SRP. In March 1998 there was a long stagnant

Table 5. Loads of chemical variables (kg/day) estimated for the Durazno Stream for baseline flow and high flow conditions. Cargas de variables químicas ( $\mathrm{kg} /$ día) estimadas para el Arroyo Durazno en condiciones de caudal base y de alto caudal.

\begin{tabular}{|c|c|c|c|c|c|c|}
\hline & \multicolumn{3}{|c|}{ Baseflow condition } & \multicolumn{3}{|c|}{ High flow condition } \\
\hline & mean & $\min$ & $\max$ & mean & $\min$ & $\max$ \\
\hline SS & 171 & 32 & 573 & 14182 & 9718 & 22638 \\
\hline $\mathrm{N}-\mathrm{NH}_{4}^{+}$ & 1.92 & 0.37 & 1.92 & 116 & 8 & 385 \\
\hline $\mathrm{N}^{-\mathrm{NO}_{3}}{ }^{-}$ & 2.04 & 0.18 & 2.04 & 83 & 53 & 128 \\
\hline $\mathrm{N}^{-\mathrm{NO}_{2}^{-}}$ & 0.30 & 0.06 & 0.56 & 18 & 11 & 34 \\
\hline SRP & 1.63 & 0.36 & 3.54 & 110 & 62 & 179 \\
\hline POC & 5.90 & 0.59 & 13 & 548 & 270 & 832 \\
\hline TOC & 90 & 27 & 128 & 8912 & 2820 & 13688 \\
\hline DOC & 84 & 27 & 115 & 8364 & 2079 & 12856 \\
\hline $\mathrm{Ca}^{+2}$ & 186 & 173 & 205 & 2279 & 1121 & 2949 \\
\hline $\mathrm{Mg}^{2+}$ & 134 & 94 & 134 & 1503 & 1021 & 1986 \\
\hline $\mathrm{Na}^{+}$ & 1464 & 1028 & 1478 & 17590 & 8416 & 21798 \\
\hline $\mathrm{K}^{+}$ & 78 & 63 & 78 & 3466 & 2522 & 4966 \\
\hline $\mathrm{HCO}_{3}^{-}$ & 2972 & 2482 & 3448 & 55152 & 45852 & 70813 \\
\hline $\mathrm{SO}_{4}^{2-}$ & 506 & 430 & 950 & 6961 & 5753 & 8485 \\
\hline $\mathrm{Cl}^{-}$ & 1108 & 699 & 1108 & 7858 & 4601 & 10214 \\
\hline
\end{tabular}


period, characterized by a high total runoff and high concentrations and loads of ammonium and phosphate in the stream water. During this period, litter decomposition might have initially released nutrients, which were then transported to the stream by leaching. A similar observation was reported by Villar et al. (2001) for marshes. During extended storm events over soils with low permeability, the total runoff remains in the basin for a long time; thus, nitrate in the drain flow tends to reduce to ammonium (Withers \& Lord, 2002). The increase in orthophosphate could be explained by changes in Eh-potential, which could produce a mobilization of phosphate from the soils. While oxygen saturation in water decreases, $\mathrm{Fe}^{+3}$ constituents will be reduced to $\mathrm{Fe}^{+2}$, thus loosing their phosphate-holding capacity (Honisch et al., 2002).

According to the bi-dimensional plane defined by $\mathrm{PC} 1$ and $\mathrm{PC} 3$, higher negative scores might correspond to worse water quality samples, but these cases were not found in the present study.

Although calcium, sodium, and potassium are considered the major cations in drainage waters (Thompson \& Troeh, 1980), their loads increased in lower proportion than stream discharge. Instead, the loads of ammonium, nitrates, and SRP increased in around the same proportion. The input of nitrogen and phosphorus to stream water due to runoff from range manure and agricultural activities (Freifelder et al., 1998; Nash and Halliwell, 2000), was also estimated in this study for the Durazno Stream through the increase in nutrient loads. A decreased infiltration due to low permeability would favor nutrient runoff, thus increasing the vulnerability of the Durazno Stream to an increasing fertilization of the soils of its basin. The loads of suspended solids, POC and TOC increased in higher proportions than stream discharge, suggesting an input by runoff that is related to the risk of hydric erosion of the basin soils.

Taking into account the current point of view on nutrient management in agricultural areas (Schröder et al., 2004), the lack of hydrological records in the present study area represents a serious inconvenient for the management of nutrients, pesticides and other contaminating agents. The values of stream discharge estimated in situ were similar to those estimated using the IUH model. Nevertheless, in future studies, the accuracy of estimations and statistical analyses could be improved by increasing the number of discharge measurements in situ.

The individual components of the nitrogen and phosphorus cycles, and the estimation of the inputs of these elements into agro-ecosystems are only partially known in the area of the Pampas. Likewise, losses of nutrients in these ecosystems are practically unknown, not only in the Pampas but also worldwide (Cassman et al., 2002). Therefore, for an efficient management of nutrients, it is imperative to know these features. The losses of nitrogen and phosphorus, herein estimated as the loads transported by the stream after rainfall events, represent just a portion of the total losses by the system. In any case, such loads are an alert about the risk of contamination of surface waters. Taking into account the expansion of agriculture and technology in the Pampas area during the nineties (Viglizzo et al., 2002), the most efficient fertilization strategies should be promoted in order to diminish the nutrients' load on the environment, thus minimizing the risk of contamination of both surface waters and water tables.

\section{ACKNOWLEDGMENTS}

We thank the Prefectura Naval Argentina for their logistic support during our sampling. The authors would like to thank Dr. E. Barrera Oro and two anonymous reviewers for their comments on an earlier version of the manuscript.

\section{REFERENCES}

APHA. 1992. Métodos normalizados para el análisis de aguas potables $y$ residuales, $17^{\text {th }}$ ed. Díaz de Santos S. A. Madrid.1804 pp.

BERNAL, S., A. BUTTURINI, A. \& F. SABATER. 2002. Variability of DOC and nitrate responses to 
storm in a small Mediterranean forested catchment. Hydrol. Earth Syst. Sci. 6(6): 1031-1041.

BRAS, R. 1990. Hydrology. An Introduction to Hydrological Science. Addison-Wesley. Berkeley. $643 \mathrm{pp}$.

CASSMAN, K. G., A. DOBERMANN \& D. T. WALTERS. 2002. Agroecosystems, nitrogen-use efficiency, and nitrogen management. Ambio, 31(2): $132-140$.

CLARK, C. O. 1945. Storage and the Unit Hydrograph. Transactions of American Society Civil Enginers, 110: 1419-1488.

FAGGI, A. M., M. O. ARRIAGA \& S. S. ALISCIONE. 1999. Composición florística de las riberas del Río Reconquista y sus alteraciones antrópicas. Revista del Museo Argentino de Ciencias Naturales, n.s., 1(1): 1-6.

FREIFELDER, R. R., S. V. SMITH \& R. H. BENNETT. 1998. Cows, humans and hydrology in the nitrogen dynamics of a grazed rural watershed. Journal of Environmental Management 52: 99. 111.

GENSTAT Release 7.1 (2003). Published by VSN International, Oxford, UK. 912 pp.

GOLTERMAN, H., R. CLYMO \& M. OHNDTAD. 1978. Methods for the physical and chemical examination of freshwaters. Blackwell Scientific Publication. Oxford. 166 pp.

GORDON, B. N. D., T. A. McMAHON \& B. L. FINLAYSON. 1994. Stream Hydrology. An introduction for ecologists.John Wiley \& Sons. N.Y. 526 pp.

HOGGAN, D. H. 1989. Computer-assisted floodplain hydrology and hydraulics. Mc Graw-Hill. N. Y. 518 pp.

HONISCH, M., C. HELLMEIER \& K. WEISS. 2002. Response of surface and subsurface water quality to land use changes. Geoderma, 105: 277 298.

INTA. 1997. Cartas de suelos de la República Argentina, Hoja 3560-18, General Las Heras. Instituto Nacional de Tecnología Agropecuaria. Buenos Aires.

JARVIE, H. P., B. A. WHITTON \& C. NEAL. 1998. Nitrogen and phosphorus in east coast British rivers: speciation, sources and biological significance. Sci Total Environ., 210/211:79-109

KIRPICH, Z. P. 1940. Time of concentration of small agricultural watersheds. Civil Engineering, 10(6): 342.

LÓPEZ, L. C., A. MAGDALENO, L. de CABO, M. F. NORIEGA, M. BASSI, S. ARREGHINI, G.
BASSOLS, M. WAGNER \& J. MORETTON. 1998. Estudios de mutagenicidad, inhibición del crecimiento algal y contaminación química en aguas superficiales de un río urbano de Buenos Aires, Argentina. Rev. Int. Contam. Amb., 14(1): 27-37.

MACKERETH, F., J. HERON \& J. TALLING. 1989. Water Analysis: some revised methods for limnologists, $2^{\text {ond }}$ ed. Freshwater Biological Association, Scientific Publication No. 36. Cumbria, UK. 120 pp.

MAIDMENT, D. R. (ed.).1992. Handbook of Hydrology, McGraw Hill. 1424 pp.

McCUEN, R. H. 2002. Approach to confidence interval estimation for curve numbers. Journal of Hydrologic Engineering, 7(1): 43-8.

MERCADO, L. M. 1999. Consideraciones acerca de la calidad de las aguas de seis sistemas lóticos de la Provincia de Buenos Aires (Argentina). Asociación para la Protección de la Naturaleza, Boletín Científico, 13(38): 10-16.

MODENUTTI, B. E. 1987. Caracterización y variación espacial del zooplancton del Arroyo Rodríguez (Provincia de Buenos Aires, Argentina). Anales del Instituto de Ciencias del Mar y Limnología de la Universidad Autónoma de México, 14(1): 21-8.

MORELlO, J. y S. D. MATTEUCCI. 1999 a. Biodiversidad y fragmentación de los bosques en la Argentina. In: Biodiversidad y Uso de la tierra. S. D. Matteucci, O. T. Solbrig, J. Morello, y G. Halffter (eds.): 463-489. Eudeba, Buenos Aires, Argentina.

MORELLO, J. \& S. D. MATTEUCCI. 1999 b. El difícil camino al manejo rural sostenible en la Argentina. In: Biodiversidad y Uso de la Tierra. S. D. Matteucci, O. T. Solbrig, J. Morello, y G. Halffter. (eds): 41-54. Eudeba, Buenos Aires, Argentina.

NASH, D. M. \& D. J. HALLIWELL. 2000. Tracing phosphorous transferred from grazing land to water. Wat. Res., 34(7): 1975-1985.

PLA, L. E. 1986. Multivariate Analysis: Principal Components Methods, Washington, DC: Organization of American States. 94 pp.

PRAT, N. \& J. V. WARD. 1994. The tamed river. In: Limnology now. A paradigm of planetary problems. R. Margalef (ed): 219-34. Amsterdam: Elsevier Science B.V.

SECRETARIAT OF THE WORLD METEREOLOGICAL ORGANIZATION. 1996. Normales cli- 
matológicas para el período 1961 - 1990. Report No. 847. WMO Region 3: Sudamérica, Argentina, 257-270.

SCHRÖDER, J. J., D. SCHOLEFIELD, F. CABRAL $\&$ G. HOFMAN. 2004. The effects of nutrient losses from agriculture on ground and surface water quality: the position of science in developing indicators for regulation. Environmental Science \& Policy, 7: 15-23.

SOIL CONSERVATION SERVICE. 1972. National Engineering Handbook, SCS United States Department of Agriculture. Washington, DC. USA.

SOLBRIG, O. T. 1999 a. Biodiversidad, desarrollo económico y sustentabilidad en la pampa argentina. In: Biodiversidad y Uso de la Tierra. S. D. Matteucci, O. T. Solbrig, J. Morello, y G. Halffter. (eds): 107-130. Eudeba, Buenos Aires, Argentina.

SOLBRIG, O. T. 1999 b. Observaciones sobre biodiversidad y desarrollo agrícola. In: Biodiversidad y Uso de la Tierra. S. D. Matteucci, O. T. Solbrig, J. Morello, and G. Halffter (eds): 29-40. Eudeba, Buenos Aires, Argentina.

STRICKLAND, J. \& T. PARSONS. 1968. A practical Handbook for Seawater Analysis. Journal Fisheries Research Board of Canada, 167. 311 pp.

THOMPSON, L. M. \& F. R. TROEH. 1980. Los suelos y su fertilidad, $4^{\text {th }}$ ed. Barcelona: Reverté. 649 pp.

USDA. 1999. Soil Taxonomy. A Basic System of Soil Classification for Making and Interpreting Soil
Surveys. $2^{\text {nd }}$ ed. Soil Survey Staff, United States Department of Agriculture, Natural Resources Conservation Service. Agriculture Handbook Number 436. 869 pp.

USEPA. 1986. Quality criteria for water. United States Environmental Protection Agency 440/586-001. Washington, DC., USA. 256 pp.

VEGA, M., R. PARDO, E. BARRADO \& L. DEBAN. 1998. Assessment of seasonal and polluting effects on the quality of river water by exploratory data analysis. Water Research, 32 (12): 3581-3592.

VILLAR, C. A., L. I. de CABO, P. VAITHIYANATHAN \& C. BONETTO. 2001. Litter decomposition of emergent macrophytes in a floodplain marsh of the Lower Paraná River. Aquatic Botany, 70: 105-116.

VIGLIZZO, E. F., A. J. PORDOMINGO, M. G. CASTRO \& F. A. LÉRTORA. 2002. La sustentabilidad ambiental de la agricultura pampeana: ¿oportunidad o pesadilla? Ciencia Hoy, 12(68): 38-51.

WILSON, B. \& W. BROWN. 1992. Development and evaluation of a dimensionless unit hydrograph. Water Resources Bulletin American Association, 28(2): 397-408

WITHERS P. J. A. \& E. I. LORD. 2002. Agricultural nutrient inputs to rivers and groundwaters in the UK: policy, environmental management and research needs. The Science of the Total Environment, 282-283: 9-24. 